\title{
Major Opportunities of Blue Economy Development in Bangladesh
}

\author{
M. Gulam Hussain ${ }^{1 *}$, Pierre Failler ${ }^{2}$, A. Al Karim ${ }^{3}$ and M. Khurshed Alam ${ }^{3}$ \\ ${ }^{1}$ EU-BGD Joint Collaboration on Blue Economy, Maritime Affairs Unit, Ministry of Foreign Affairs, \\ Segunbagicha, Dhaka 1000, Bangladesh \\ ${ }^{2}$ Economics and Finance Group, Portsmouth Business School, University of Portsmouth, Richmond \\ Building, Portland Street, Portsmouth, PO1 3DE, UK \\ ${ }^{3}$ Maritime Affairs Unit, Ministry of Foreign Affairs, Segunbagicha, Dhaka 1000, Bangladesh
}

\begin{abstract}
This paper elucidates the major opportunities of economic sectors to the development of blue economy and highlights the constraints in achieving this goal in Bangladesh. The productive economic sectors of blue economy are emphasised and considered in harnessing the full utilization of ocean based resources within the present maritime boundary of Bangladesh. If these ocean based resources are managed by proper planning and intersectoral coordination of public-private partnership and investment, it will certainly generate strong foundation for earnings and economic benefits under the approach of blue economy.

On the other hand, if marine based economic resources with potential sectors be managed and governed by principles of biodiversity protection, conservation and efforts for care are intertwined with a vision of scientific understanding, and then the blue economy can create some opportunities to resolve the issues of climate changes at the coastal areas. It might also generate jobs and bring about tangible changes in the lives and livelihood of the millions of people living along the coastline, in islands and across Bangladesh. A coordinated approach with concerned stakeholder's groups is required to determine the extent to which the constraints mentioned in the discussion section can be turned into opportunities, and to ensure that development of the blue economy does not result in unsustainable and damaging practices for the benefit of short term economic gains over longer terms sustainable economic and social benefits. In particular, for Bangladesh, this involves developing a maritime/marine spatial planning directive to detail coordination between blue economy sectors and stakeholders to ensure sustainable development.
\end{abstract}

\section{Introduction}

In Bangladesh, discussions on blue economy started after the settlement of maritime boundary delimitation dispute with Myanmar (2012) and India (2014). So, the Government has recently started dialogues with the stakeholders to adopt the concept of blue economy across relevant policies and plans. The objective is to exploiting untapped potential of the marine environment using useful solutions and innovations for increasing food security, alleviating poverty, improving nutrition and health, creating jobs, lifting trade and industrial profiles while protecting ecosystem health and biodiversity, and also improving regional security and peace. There is no doubt that sea-related subjects like expansion of international trade, use of marine mineral resources for long-term energy security, proper management of marine fish resources and protecting marine environment and bio-diversity would determine Bangladesh's future development and economic growth (MOFA 2014a). Today, 90\% of the 
country's trade is transported through the sea. (Alam 2014). The fish stocks and other inorganic resources in the Bay of Bengal $(\mathrm{BoB})$ can contribute greatly to the economy of the country. . It can be achieved if resource management is governed by the principles of the protection of the oceans, including biodiversity, ecological function and sustaining environmental services. The country like Bangladesh, which currently have an underdeveloped blue economy, are well positioned to develop sectors of the blue economy. For example, fisheries and coastal aquaculture offer huge potential for the provision of food and livelihoods, respecting ecological parameters, creating sustainable employment and producing high value species for international export markets. However, a strategic approach, supported with a governance structure is imperative to developing the blue economy otherwise the example of fisheries and coastal aquaculture development given here could easily lead to resource exploitation e.g. biodiversity loss and ultimately depletion e.g. loss of ecological function. The objective of this paper to highlight the major opportunities of economic sectors related to the development of blue economy in Bangladesh and touches the constraints in achieving this goal.

The paper is framed out as follows: in the next section the settlement of maritime boundary of Bangladesh and major opportunities of the available economic sectors have been explained comprehensively; a discussion section and finally completed with a paragraph of conclusion.

\section{Settlement of Maritime Boundary of Bangladesh}

The recent two verdicts of maritime boundary of Bangladesh with Myanmar and India, allowed the country to exercise sovereign right to 118,813 sq. $\mathrm{Km}$ of waters extending up to 12 nautical miles of territorial sea and a further Exclusive Economic Zone (EEZ) of 200 nautical miles into the sea and Continental Shelf extending up to $354 \mathrm{~nm}$ from the Chittagong coast (MoFA, 2014b). It is obviously a vast area and commercial and economic interests together with environmental stakes there, warrant proper protection and security and this confirmation is the outstanding achievement for Bangladesh (Bhuiyan et al. 2015). The Fig. 1 shows below the present maritime boundary/maritime province of Bangladesh (Chaudhury, 2017). 


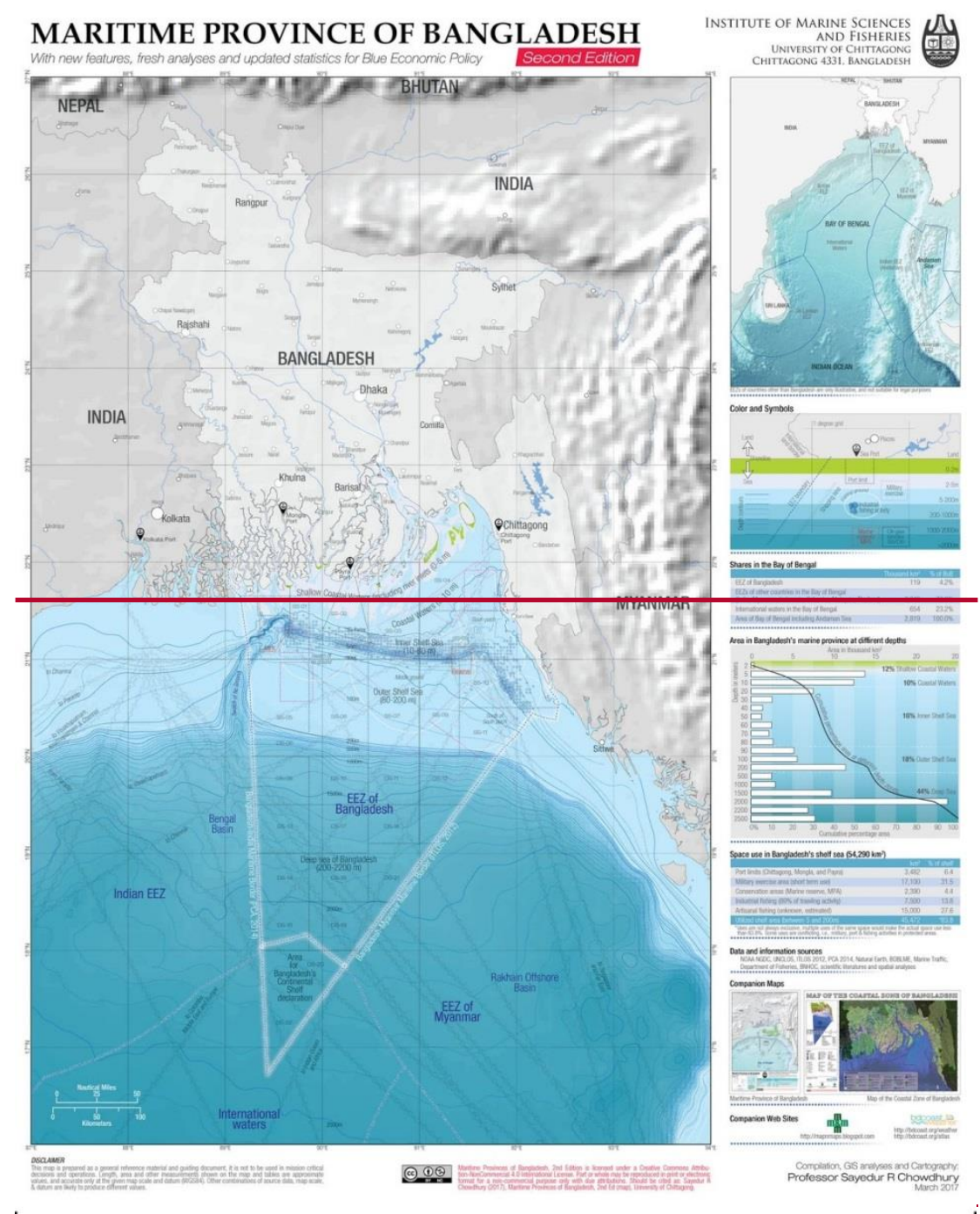

Fig.1 Maritime province of Bangladesh (Chowdhury, 2017)

\section{Major Opportunities of Economic Sectors of Blue Economy}

In view of harnessing the full utilization of ocean based resources within the present maritime boundary of Bangladesh, a range of productive economic sectors need to be emphasised and considered, viz. i) Marine Fisheries and Aquaculture; ii) Marine NonTraditional Species Culture; iii) Marine Biotechnology; iv) Carbon Sequestration; v) Oil, Gas and Minerals Mining; vi) Ocean Renewable Energy; vii) Sea Salt Production; viii) Marine Trade, Shipping and Transport; ix) Marine Tourism; x) Marine Education and Research; xi) Maritime Surveillance; xii) Marine Spatial Planning etc. (Fig. 2). Under blue economy approach within a comprehensive framework of ecosystem based management if ocean spaces are properly planned and managed to carryout inter-sectoral coordination with publicprivate partnership and investment that will certainly generate strong foundation for huge earnings and economic benefits for the country. 


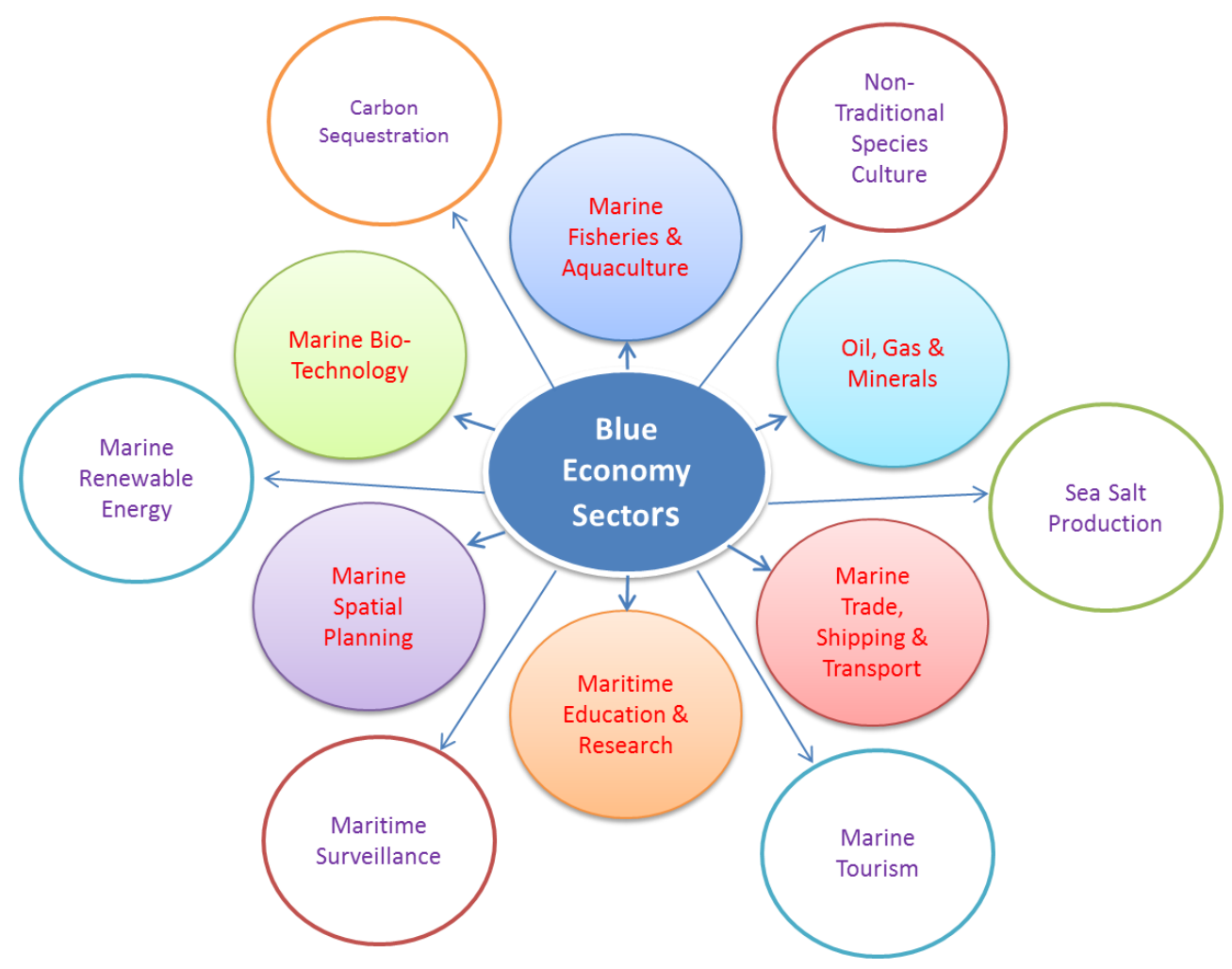

Fig. 2. Major sectors related to blue economy in Bangladesh

Bay of Bengal and coastal regions are the backbone of national economy of Bangladesh. The blue economy can create enormous opportunities to resolve the issues of climate changes at the coastal areas by addressing the challenges. On the other hand, it might generate jobs for millions and bring about tangible changes in the lives and livelihood of the millions of people living along the coastline, in islands and across Bangladesh, if the marine based economic resources belonging with many sectors are managed and governed by principles of biodiversity protection, conservation is community-led and efforts for care are intertwined with a vision of scientific understanding. The past and present status and trends and future potentials of marine based economic resources (Living, non-living and potential other resources) within the identified sectors are summarised in Table 1 and major opportunities of these sectors are detailed in the following paragraphs.

Table 1. Major marine based economic resources within the identified sectors along with their past and present trends and future potentials (modified after Anon 2016)

\begin{tabular}{|l|l|l|l|}
\hline $\begin{array}{l}\text { Marine } \\
\text { Resources }\end{array}$ & $\begin{array}{l}\text { Economic } \\
\text { Sectors }\end{array}$ & Past and Present Status and Trends & Future Potentials \\
\hline $\begin{array}{l}\text { Living } \\
\text { Resources }\end{array}$ & $\begin{array}{l}\text { Marine } \\
\text { Fisheries and } \\
\text { Aquaculture }\end{array}$ & $\begin{array}{l}\text { Marine fishing in shallow \& shelf } \\
\text { waters in existing fishing grounds } \\
\text { Improved extensive shrimp farming } \\
\text { practice; Mariculture of sea bass, } \\
\text { grouper, marine eel, pomfret, mullets } \\
\text { etc. absent; Soft shell carb culture } \\
\text { limited }\end{array}$ & $\begin{array}{l}\text { Explore large pelagic fish } \\
\text { harvesting; Long line } \\
\text { fishing of Tuna \& tuna like } \\
\text { fishes } \\
\text { Hatchery based seed } \\
\text { production \& mariculture } \\
\text { of important marine spp. } \\
\text { viz. sea bass, grouper, } \\
\text { marine eel, pomfret, }\end{array}$ \\
\hline
\end{tabular}




\begin{tabular}{|c|c|c|c|}
\hline & & & $\begin{array}{l}\text { mullets etc. } \\
\text { Intensify soft shell crab } \\
\text { farming using hatchery } \\
\text { produced seeds }\end{array}$ \\
\hline & $\begin{array}{l}\text { Marine Non- } \\
\text { Traditional } \\
\text { Species }\end{array}$ & $\begin{array}{l}\text { Seaweed, marine algae culture absent; } \\
\text { No marine oyster, mussel, sea } \\
\text { cucumber, sea urchin etc. culture }\end{array}$ & $\begin{array}{l}\text { Initiation of seaweed \& } \\
\text { marine algae culture; } \\
\text { Initiate shell fish breeding } \\
\& \text { culture }\end{array}$ \\
\hline & $\begin{array}{l}\text { Marine } \\
\text { Biotechnology }\end{array}$ & $\begin{array}{l}\text { Biotechnology not yet utilized for any } \\
\text { marine living \& biological resources }\end{array}$ & $\begin{array}{l}\text { Application of marine } \\
\text { biotechnological tools for } \\
\text { developing pharmaceutical } \\
\text { drugs/chemicals \& other } \\
\text { products as human food }\end{array}$ \\
\hline & $\begin{array}{l}\text { Blue Carbon } \\
\text { Sequestrations }\end{array}$ & $\begin{array}{l}\text { Estimates of carbon sequestration in } \\
\text { vegetated estuaries and coastal habitat } \\
\text { were not yet properly recorded; } \\
\text { Mangrove forests reducing trend due to } \\
\text { deforestation }\end{array}$ & $\begin{array}{l}\text { Bio-mitigation of climate } \\
\text { change by blue carbon } \\
\text { sequestrations by } \\
\text { restoration of overall } \\
\text { coastal ecosystems and } \\
\text { habitats i.e. Sequestering } \\
\text { and storing carbon at } \\
\text { mangroves, saltmarsh and } \\
\text { sea grass ecosystems. }\end{array}$ \\
\hline \multirow[t]{2}{*}{$\begin{array}{l}\text { Non- } \\
\text { living } \\
\text { Resources }\end{array}$} & $\begin{array}{l}\text { Oil, Gas \& } \\
\text { Minerals }\end{array}$ & $\begin{array}{l}\text { Oil \& gas exploration \& extraction } \\
\text { limited; Coastal sand mining \& } \\
\text { dredging }\end{array}$ & $\begin{array}{l}\text { Intensify oil \& gas } \\
\text { extraction; Explore \& } \\
\text { update potential mining }\end{array}$ \\
\hline & Sea Salt & Traditional solar evaporation & $\begin{array}{l}\text { Salt refining \& marketing } \\
\text { using modern technologies }\end{array}$ \\
\hline \multirow[t]{6}{*}{$\begin{array}{l}\text { Potential } \\
\text { Other } \\
\text { Resources }\end{array}$} & $\begin{array}{l}\text { Marine } \\
\text { Renewable } \\
\text { Energy }\end{array}$ & Solar, wave \& wind energy limited use & $\begin{array}{l}\text { Implementation of using } \\
\text { wind, wave, solar, tide, } \\
\text { water current etc. as marine } \\
\text { renewable energy }\end{array}$ \\
\hline & $\begin{array}{l}\text { Marine Trade, } \\
\text { Shipping and } \\
\text { Transport }\end{array}$ & Port shipping \& transport limited & $\begin{array}{l}\text { Sea born trade \& fleet use } \\
\text { need to be expanded }\end{array}$ \\
\hline & Tourism & Coastal tourism limited & $\begin{array}{l}\text { Expansion of tourism in sea } \\
\text { beaches \& in existing \& } \\
\text { newly developed islands }\end{array}$ \\
\hline & $\begin{array}{l}\text { Maritime } \\
\text { Education and } \\
\text { Research }\end{array}$ & $\begin{array}{l}\text { Maritime human resource development } \\
\text { limited; Research on marine and ocean } \\
\text { related aspects also scanty }\end{array}$ & $\begin{array}{l}\text { Expanding marine } \\
\text { education \& research at } \\
\text { existing \& newly } \\
\text { established institutions }\end{array}$ \\
\hline & $\begin{array}{l}\text { Maritime } \\
\text { Surveillance }\end{array}$ & $\begin{array}{l}\text { Bangladesh Navy/Coast Guard watch } \\
\text { the marine resources }\end{array}$ & $\begin{array}{l}\text { These services expanding } \\
\text { to secure all marine } \\
\text { resources of the extended } \\
\text { boundaries }\end{array}$ \\
\hline & $\begin{array}{l}\text { Marine } \\
\text { Spatial } \\
\text { Planning }\end{array}$ & $\begin{array}{l}\text { No MSP has yet been formulated, } \\
\text { designed and implemented }\end{array}$ & $\begin{array}{l}\text { MSP will be the guiding } \\
\text { tools for BE to build up the } \\
\text { strategy for management } \\
\text { and full utilization of } \\
\text { maritime resources }\end{array}$ \\
\hline
\end{tabular}




\section{Marine fisheries and aquaculture}

The marine resources of Bangladesh are blessed with rich coastal and marine ecosystems, hosting a wide range of biodiversity, such as fishes, shrimps, molluscs, crabs, mammals, seaweeds, etc. Bay of Bengal and coastal region is one of the most important areas of national economy of Bangladesh. Current (2015) total fish production of Bangladesh is 3.68 million tonnes, among which capture fisheries contributes 1.0 million tonnes (28\%); aquaculture 2.2 million tonnes (56\%) and marine fisheries 0.6 million tonnes (16\%). In fact, present (2015) contribution to GDP is $3.69 \%$. As a single species, Hilsa (Tenualosa ilisha), accounts nearly about $42 \%$ of total marine catches and $10.5 \%$ of the total fish production of the country. In fact, marine aquaculture is mainly based extensively with tiger shrimp (Penaeus monodon) culture and at limited scale with soft shell crab (Scylla serrata) culture And major export is being presently dominated by frozen shrimp and live mud carb and contribution of fin fishes as export items are scanty. In the year 2015, total shell fish and fin fish exported from Bangladesh about US\$ 582 million (DoF, 2016).

In comparison to inland capture and culture fisheries, production of marine capture fisheries is meagre because almost all of Bangladesh's marine fishing is carried out in shallow and shelf waters, beyond which no fishing is being currently done due to lack of vessel capacity and appropriate fishing technologies. But under the concept of blue economy of Bangladesh, marine fisheries and aquaculture sector are extremely promising to flourish side by side with the other listed sectors of maritime resources. The potentials and opportunities of capture fisheries, coastal aquaculture and marine non-traditional species culture have been separately and briefly described as follows:

\section{a. Marine Capture Fisheries}

To exploit multi species marine fish resources, numerous fishing gears are used in Bangladesh. Artisanal small scale fishery contributes $86.8 \%$; i.e. 0.51 million tonnes (DoF 2016) of the total marine catch, which includes gill nets, set bag net, seine net, push net, hook and line, trammel net etc. mostly used for fishing within $10-30$ meters water depth. Large industrial fishery (Trawl fishery) contributes 14.2\%; i.e. 0.084 million tonnes (DoF 2016) of total marine production. Large trawlers are used for mostly penaeid shrimps and fin fish fishing within the depth of 40 - 100 meters (Hussain and Rahman, 2010). In particularly for marine capture fisheries, Bangladesh must come out of the traditional fishing practices and harness the potentials of moving towards beyond the existing fishing grounds to harvest large pelagic fishes from deeper zones within $200 \mathrm{~nm}$ of EEZ and even up to the high seas. In view of doing this, the first important thing is to conduct a thorough survey to accomplish stock assessment of marine fishes in $\mathrm{BoB}$ area to explore more new fishing ground(s). Department of Fisheries (DoF) under the auspices of Ministry of Fisheries and Livestock (MOFL) has already procured a modern survey vessel, which already initiated stock assessment survey under the auspices of FAO technical assistance within the settled maritime boundary of Bangladesh.

Afterwards, the country should have to adopt appropriate deep sea fishing technologies i.e. long line and hook fishing and using supporting gears and vessels for harvesting large pelagic fish i.e. tuna and tuna like species. To get access for tuna fishing at 
BoB of Indian Ocean, Bangladesh should immediately be a member state of IOTC. It is expected that the country would be to earn billions and trillions of foreign exchange by exporting tuna fillets and other value added items to the international markets. Rehabilitation of Hilsa fishery is another important task that needs to be intervened as transboundary issue. At present $50-60 \%$ of global hilsa catch takes place in the coastal and marine waters of Bangladesh, 20-25\% in Myanmar, 15-20\% in India and the remaining 5-10\% in other countries (Hossain et al. 2014). Hilsa as transboundary species of BoB, a joint effort among Bangladesh, India, Myanmar might be effective to prevent the harvest hilsa juveniles and protect the mature brood stock during the banning period already initiated and implemented successfully by the Govt. of Bangladesh. Similarly, regulation can be adopted indiscriminate harvesting of gravid mother shrimp, P. monodon by trawling at the depth of $10-40$ meters of inshore marine waters. And it will certainly conserve the tiger shrimp brood stocks, which will ultimately be used at onshore shrimp hatcheries to support seeds for shrimp farming at the coastal farms. These opportunities of marine capture are summarized in Table 2.

Table 2. Opportunities for marine capture fisheries in BoB.

\begin{tabular}{|l|l|l|l|}
\hline Programs & Stocks & Marine areas & Actions \\
\hline $\begin{array}{l}\text { Explore and harvesting large } \\
\text { pelagic fishery }\end{array}$ & $\begin{array}{l}\text { Tuna and } \\
\text { tuna like } \\
\text { species } \\
\text { aithin EEZ } \\
\text { and beyond }\end{array}$ & $\begin{array}{l}\text { Adopt long line fishing; } \\
\text { assessment of stocks \& identify } \\
\text { the harvesting season; having full } \\
\text { membership of IOTC \& sharing } \\
\text { information }\end{array}$ \\
\hline Rehabilitation of hilsa fishery & Hilsa shad & $\begin{array}{l}\text { Within coastal } \\
\text { \& territorial } \\
\text { waters }\end{array}$ & $\begin{array}{l}\text { Ban \& stop harvesting juveniles; } \\
\text { Sharing regulation issues with } \\
\text { neighbouring countries }\end{array}$ \\
\hline $\begin{array}{l}\text { Management of gravid mother } \\
\text { shrimp }\end{array}$ & $\begin{array}{l}\text { Tiger shrimp, } \\
\text { P. monodon }\end{array}$ & Inshore waters & $\begin{array}{l}\text { Development of strategy, } \\
\text { regulate and control harvesting }\end{array}$ \\
\hline Explore new fishing grounds & $\begin{array}{l}\text { Identify new } \\
\text { marine stocks }\end{array}$ & $\begin{array}{l}\text { Deeper areas of } \\
\text { the ocean }\end{array}$ & $\begin{array}{l}\text { Diversify fishing areas to avert } \\
\text { risks associated with overfishing } \\
\text { of certain fish stocks. }\end{array}$ \\
\hline
\end{tabular}

\section{b. Marine Aquaculture}

Bangladesh is one of the champions ( $5^{\text {th }}$ in ranking) among the top 10 countries of the world for freshwater aquaculture. The tremendous success achieved due to innovation and development of artificial breeding techniques and various aquaculture technologies and extensive dissemination of those at farm level. The leading freshwater aquaculture species are carps, tilapias, catfishes (Pangasius and Asian catfish) and climbing perch in Bangladesh., In respect of marine aquaculture farming, Bangladesh is still lagging behind other countries of Siuth East Asia; viz. China, Myanmar, Philippines and Vietnam. There are opportunities to initiate and introduce both brackish and marine fish species aquaculture (Table 3). Lessons can be learned from the success of freshwater aquaculture breeding and farming of the country including adopting various marine aquaculture farming technologies from the other countries.

In regard to intensification of tiger shrimp farming, use of traditional and extensive farming practices can be avoided by initiating semi-intensive culture systems in most of the 
shrimp farms with the introduction of domestication of tiger shrip brood stocks, production of healthy shrimp seed ie. Specific Pathogen Free (SPF) seeds; exportation of quality feeds and adopting good aquaculture practices. Tiger shrimp is predominantly cultivated in the coastal districts of Satkhira, Khulna, Bagerhat and Cox's Bazar, which culture areas are expanded rapidly between 1970 and 1990, to about 183,221 hectares (Belton et al. 2011). By adopting semi-intensive farming, shrimp production can be achieved $4000-6000 \mathrm{~kg} / \mathrm{ha} / \mathrm{crop}$ against the present low and minimum production $(60-230 \mathrm{~kg} / \mathrm{ha}$, cited by Hossain et al. 2014).

Breeding and farming of sea bass, Lates calcarifer, unlike Philippines, Thailand and Vietnam could be also initiated as an important high value aquaculture species. If artificial breeding and seed production techniques are evolved successfully then land based farming at onshore and case culture at offshore suitable locations can easily be expanded. As sea bass is a carnivore species a special feeding method could be introduced including formulation of high protein feeds. Similarly, other brackish and marine water fish species viz. mullets, pomfrets etc. artificial breeding and farming technologies can also be evolved and implemented. To enrich fin fish mariculture, saline tolerant tilapia species either existing GIFT strain or Molobicus strain, which has already been developed by a France company???? in Philippines, could successfully be utilized at suitable coastal farms as an alternative crop of shrimp aquaculture.

One of the most promising mariculture shellfish species is mud crab, Scylla serrata, available in brackish ecosystem in Bangladesh. Crab fattening and export to other countries are being done under limited scale. Soft shell crab farming (presently being practised under limited scale in Sathkhira, , Cox's Bazar and Moheshkhali areas) and is an innovative and new technology, which could extensively be practised in the feasible other coastal areas like Cox's Bazar, Moheshkhali, Kutubdia, Chittagong, Khulna Bhola, Barishal regions. To sustain and intensify this practice, artificial breeding and seed production in the hatcheries will extremely be essential and for this purpose shrimp hatchery faculties in coastal region can be utilized.

Table 3. Opportunities of mariculture systems development at coastal areas of Bangladesh

\begin{tabular}{|c|c|c|}
\hline Mariculture options & Technology Adoption & Locations \\
\hline $\begin{array}{l}\text { Ouality seed production \& } \\
\text { intensification of tiger shrimp } \\
\text { farming }\end{array}$ & $\begin{array}{l}\text { Domestication of shrimp brood } \\
\text { stocks, SPF seed production \& } \\
\text { Semi-intensive farming }\end{array}$ & $\begin{array}{l}\text { Khulna, Shatkhira, Bagerhat, } \\
\text { Sonapara, Ukhiia and Chakria } \\
\text { at Cox;s Bazar }\end{array}$ \\
\hline $\begin{array}{l}\text { Seabass (Lates calcarifer) } \\
\text { breeding and farming }\end{array}$ & $\begin{array}{l}\text { Development of hatchery } \\
\text { breeding techniques; In shore } \\
\text { and off-shore cage farming }\end{array}$ & $\begin{array}{l}\text { In near shore and off shore } \\
\text { areas i.e. Moheshkhali- } \\
\text { Kutubdia channel, Sonadia } \\
\text { island, Saint Martin island, } \\
\text { Dubla island. } 1 \text { \& other coastal } \\
\text { suitable regions }\end{array}$ \\
\hline $\begin{array}{l}\text { Grey mullet (Mugil cephalus) } \\
\text { breeding and farming }\end{array}$ & $\begin{array}{l}\text { Development of hatchery } \\
\text { breeding techniques; Land based } \\
\text { semi-intensive farming }\end{array}$ & $\begin{array}{l}\text { Cox's Bazar, Chittagong, } \\
\text { Khulna Bhola, Barishal \& } \\
\text { other coastal suitable regions }\end{array}$ \\
\hline $\begin{array}{l}\text { Saline tolerant tilapia } \\
\text { (GIFT/Molobicus strain) } \\
\text { farming }\end{array}$ & $\begin{array}{l}\text { Development of hatcheries for } \\
\text { monosex seed production; Land } \\
\text { based and off-shore cage farming }\end{array}$ & $\begin{array}{l}\text { Cox's Bazar, Chittagong, } \\
\text { Khulna Bhola, Barishal \& in } \\
\text { near shore and off shore areas } \\
\text { ie. Moheshkhali-Kutubdia } \\
\text { channel, Sonadia island, Saint } \\
\text { Martin island, Dubla island. }\end{array}$ \\
\hline
\end{tabular}




\begin{tabular}{|l|l|l|}
\hline Soft shell crab, culture & $\begin{array}{l}\text { Development of hatchery } \\
\text { breeding techniques; Land based } \\
\text { farming in the suitable brackish } \\
\text { water areas }\end{array}$ & $\begin{array}{l}\text { Cox's Bazar, Moheshkahali, } \\
\text { Kutubdia, Chittagong, Khulna } \\
\text { Bhola, Barishal \& other } \\
\text { coastal suitable regions }\end{array}$ \\
\hline Pomfret breeding and farming & $\begin{array}{l}\text { Identification of species suitable } \\
\text { for breeding and captive culture; } \\
\text { Development of breeding \& } \\
\text { culture techniques }\end{array}$ & $\begin{array}{l}\text { Cox's Bazar and other } \\
\text { suitable coastal regions }\end{array}$ \\
\hline
\end{tabular}

\section{Marine Non-Traditional Species Culture}

Opportunities also exist for mariculture of non-traditional marine living species like seaweed and other macro algae, mussel, Oyster and other shellfish (edible oysters, Crassostrea sp. Saccostrea sp, pearl oyster, Anadra sp green mussel, Pernaviridis, clam, Meretrix meretrix, Marcia opima, sea snails), sea urchin, sea cucumber etc. (Table 4). Lessons can be learned from other countries to adapt innovative technologies for initiating mariculture of these species. Bangladesh has 168 species of sea weed and other macro algae and some of them are commercially important. Identification of suitable species and development of commercial culture techniques of sea weed might benefit the country. Screening, Isolation and characterization of useful compounds from seaweed can carried out through the application different biotechnological tools. Sea weed as food items, chemicals and medicinal ingredients can be exported to earn foreign exchange. Suitable areas for sea weed and other macro algae are Cox's Bazar, St. Martin Island and other suitable coastal locations. Similarly, mussel, Oyster and other shellfish culture could also be included. Sea urchin, sea cucumber etc. living habitat can also be explored in particularly at Inani of Cox's Bazar and St. Martins island as coral basements. These marine invertebrate are used in many developing countries as valuable pharmaceuticals for cancer treatment. As there is availability of pearly oyster species in BoB, so like Japan and other countries, there is a possibility to develop marine pearl culture at suitable inshore and coastal locations of Bangladesh.

To combat climate change issue of the recent days, one of the adaptation strategies is "Integrated Multi Trophic Aquaculture (IMTA)". Open water IMTA in coastal Bangladesh would be a novel process of growing of different fin fish and shellfish with sea weeds in an integrated farm (Ahmed and Glaser, 2016). IMTA is considered as an ecosystem approach adaptation strategy to climate change which could generate environmental and economic benefit. IMTA is operated currently over 40 countries on experimental and commercial basis including Canada, Chile, China, Japan, USA and many European countries (Chopin, 2011). In Bangladesh, IMTA has taken recent consideration for research and development to diversity production (Kibria, 2016).

Table 4. Opportunities of mariculture systems development of marine non-traditional species under blue economy in Bangladesh.

\begin{tabular}{|l|l|l|}
\hline Mariculture options & Technology Adoption & Locations \\
\hline $\begin{array}{l}\text { Seaweed and other macro } \\
\text { algae culture }\end{array}$ & $\begin{array}{l}\text { Identify suitable seaweed and } \\
\text { other macro algae for culture; } \\
\text { Development and implementation } \\
\text { of commercially important }\end{array}$ & $\begin{array}{l}\text { Cox's Bazar, St. Martins and } \\
\text { other suitable coastal areas }\end{array}$ \\
\hline
\end{tabular}




\begin{tabular}{|l|l|l|}
\hline & seaweed culture techniques & \\
\hline $\begin{array}{l}\text { Mussel, Oyster and other } \\
\text { shellfish culture }\end{array}$ & $\begin{array}{l}\text { Identify suitable mussel, oyster } \\
\text { and other shellfish species for } \\
\text { culture } \\
\text { Development and implementation } \\
\text { of shellfish techniques }\end{array}$ & $\begin{array}{l}\text { Cox's Bazar, St. Martins and } \\
\text { other suitable coastal areas }\end{array}$ \\
\hline Marine pearl culture & $\begin{array}{l}\text { Identification of suitable mussel } \\
\text { \& oyster species; Use nuclei } \\
\text { placement at mental/gonad tissue } \\
\text { at pearly mussels }\end{array}$ & $\begin{array}{l}\text { Suitable inshore and coastal } \\
\text { areas }\end{array}$ \\
\hline $\begin{array}{l}\text { Explore and culture of sea } \\
\text { cucumber, sea urchin etc. }\end{array}$ & $\begin{array}{l}\text { Identification of sea cucumber } \\
\text { and sea urchin species; } \\
\text { Development and implementation } \\
\text { of suitable techniques of sea } \\
\text { cucumber and sea urchin culture } \\
\text { \& utilization }\end{array}$ & $\begin{array}{l}\text { Cox's Bazar, St. Martins and } \\
\text { other suitable coastal areas }\end{array}$ \\
\hline $\begin{array}{l}\text { Development and } \\
\text { implementation of Integrated } \\
\begin{array}{l}\text { Multi Trophic Aquaculture } \\
\text { (IMTA) }\end{array}\end{array}$ & $\begin{array}{l}\text { Integrated Fish (fin fish+shrimp) } \\
+ \text { Shellfish + Sea weed culture }\end{array}$ & $\begin{array}{l}\text { Cox's Bazar, Chittagong, } \\
\text { Khulna Bhola, Barisal \& other } \\
\text { coastal suitable regions }\end{array}$ \\
\hline
\end{tabular}

\section{Marine Biotechnology}

Biotechnology comprises a broad spectrum of scientific applications that use biological systems, living organisms, or derivatives thereof to make or modify products or to improve plants or fish/animals or to develop microorganisms for specific uses. A new era of rapidly growing gene-based biotechnology began with the understanding of DNA molecule and genome sequencing. So application of biotechnology tools as novel cross-cutting techniques have, meanwhile, been used in the field of agriculture, industry, medicine including scanty in fisheries and aquaculture all over the world. Maine biotechnology is still in the infant stage of use and exercise. Marine biotechnology is defined as the application of scientific and engineering principles to the processing of materials by marine biological agents to provide goods and services (Zilinskas et al. 1995). Marine biotechnology explores the oceans to develop novel pharmaceutical drugs, chemical products, enzymes and other industrial products and processes. It also plays a vital role in the advancement of biomaterials, health care diagnostics, fisheries and aquaculture, sea food safety, bioremediation and biofouling (Thakur and Thakur 2006).

Unlike other countries of the world, the opportunity for application of marine biotechnology in Bangladesh is highly promising. No doubt that existing living resources in particularly the marine organisms can be used as a source of new materials/products especially for application in human health care (antibiotics, anti-cancer, bioactive compounds and other pharmaceutical drugs, nutritional supplements, etc.) and nutritionally balanced food (marine fish, shrimps, crabs, molluscs, seaweed etc.). Nevertheless, numerous untapped novel microorganisms and under exploited fisheries and other living resources of BoB offers huge development potential of marine-based biotechnology to shape the creation and production of new processes, products and services (Hossain et al. 2014). Table 5 shows the scope of marine biotechnology to apply at multiple areas of sea based economic activities. 
Table 5. Scope of marine biotechnology to apply at multiple areas of sea based economic activities (Modified after Hossain et al. 2014)

\begin{tabular}{|l|l|}
\hline Area & Scope of Application \\
\hline Marine capture \\
fisheries & $\begin{array}{l}\text { Characterization/gene mapping of commercially important marine species } \\
\text { using molecular markers; Determination of population structure of } \\
\text { selected marine stocks; Post-harvest quality assessment and product } \\
\text { development of marine fish; shrimp and crabs. }\end{array}$ \\
\hline Mariculture & $\begin{array}{l}\text { Stock improvement through selective breeding \& marker-assisted } \\
\text { selection of suitable cultivable marine species; Production of probiotics } \\
\text { and metabolites for fish/shrimp/crab feed supplementation; Development } \\
\text { of PCR based technique for rapid diagnosis of infectious diseases; } \\
\text { Development of genetically engineered vaccines against devastating } \\
\text { pathogens of fish/shrimp. }\end{array}$ \\
\hline $\begin{array}{l}\text { Seaweed and other non- } \\
\text { traditional products }\end{array}$ & $\begin{array}{l}\text { Improvement of seaweed production through application of different } \\
\text { biotechnological tools (tissue culture and gene transfer); Development of } \\
\text { some useful chemicals like agar, carrageenan; alginates etc. and } \\
\text { therapeutic agents from seaweed and similar micro algae; Development of } \\
\text { chemicals and pharmaceuticals from sea cucumber and sea urchin. }\end{array}$ \\
\hline Human health care & $\begin{array}{l}\text { Production of therapeutics, pharmaceuticals, nutraceuticals, medical } \\
\text { devices, drug delivery systems, wound dressings, cell therapy, prosthetics } \\
\text { from various marine living and non-living resources. }\end{array}$ \\
\hline Food and nutrition & $\begin{array}{l}\text { Development of ingredients that modify physical properties of food, i.e. } \\
\text { gelling agents, colourants, textures and flavours, nutritional components, } \\
\text { functional foods. }\end{array}$ \\
\hline Environment & Production of biosensors, bioremediation (removing hydrocarbons) \\
\hline Energy & $\begin{array}{l}\text { Production of biofuel from microalgae as alternative source of energy } \\
\text { Input to various manufacturing units, from textiles to chemicals, to } \\
\text { biomaterials including adhesives, filters, films as well as industrial } \\
\text { processes using enzymes such as equipment cleaning and waste } \\
\text { remediation. }\end{array}$ \\
\hline Industry &
\end{tabular}

\section{Carbon Sequestration}

Carbon sequestration is a process of up taking $\mathrm{CO}_{2}$ over a long-time (i.e. several decades and centuries) into the coastal habitats having mangrove forests, intertidal saltmarshes and seagrass beds and such stored carbon often referred to as blue carbon (Trumper et al. 2009; Nellemann et al. 2009). These habitats have been found to fix carbon at a much higher rate per unit area than land based systems and be more effective at the longterm sequestration of carbon than terrestrial forest ecosystems. Coastal ecosystems can store carbon at rates estimated to be up to four times higher than mature tropical forests. In addition to providing a measure of resistance and resilience to coastal communities, the mangroves, saltmarsh and seagrass ecosystems are very effective at sequestering and storing carbon (Chowdhury et al.2015).

Globally mangroves have been reduced to $30-50 \%$ of their historical cover and $29 \%$ of seagrass habitats are estimated to have been lost in the last 150 years (Valiela et al. 2001). This trend of reducing coastal habitats, meanwhile, affecting many coastal countries of South East Asia including Bangladesh and India. It is also reported that agricultural land conversion destroyed 17,179 hectares of mangroves in India during 1975 to 2005. A further 7,554 hectares was lost due to Shrimp cultivation. Over the last 30 years some 7,500 hectares in 
Bangladesh has become submerged by rising seas. So, mangrove forests are often threatened by climate change in the Sundarbans mangrove forest of Bangladesh and India.

Bangladesh is blessed with diverse coastal habitats, such as mangrove forests, saltmarsh and seagrass beds, and the exact amount of carbon stored by these ecosystems is still an active area of research (Chowdhury et al. 2015). No information on the blue carbon sequestration by coastal habitats is readily available except the recent report of Chowdhury et al. (2015), where they summarised the estimates of carbon sequestration in vegetated estuaries and coastal habitats of Bangladesh (Table 6).

Table 6. Estimates of carbon sequestration in vegetated estuaries and coastal habitats of Bangladesh (Adapted from Chowdhury et al. 2015)

\begin{tabular}{|l|l|l|l|}
\hline Habitat & Area (ha) & Tonnes $\mathrm{CO}_{2}$-eq./ ha/yr & Total $\mathrm{CO}_{2}$ eq./ yr (tonnes) \\
\hline Mangroves & 441,455 & $4.73^{\mathrm{a}}$ & $2,088,082$ \\
\hline Saltmarshes & 111,585 & $10.16^{\mathrm{b}}$ & $1,133,704$ \\
\hline $\begin{array}{l}\text { Seagrass beds River- } \\
\text { estuary*Coastal water* } \\
<5 \mathrm{~m} \text { depth }\end{array}$ & $\begin{array}{l}660,048 \\
886,523\end{array}$ & $10.26^{\mathrm{c}}$ & Unknown $^{\mathrm{d}}$ \\
\hline
\end{tabular}

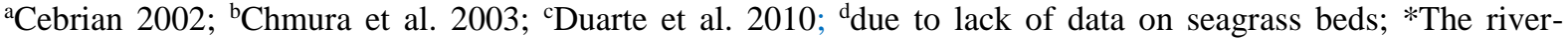
estuary and coastal shallow water systems are suitable habitats for seagrasses, but it is required to identify the seagrass beds and quantify their extent/ distribution in order to obtain the exact estimates of seagrass $\mathrm{CO} 2$ sequestration per unit area.

Hence, under present blue economy approach, the blue carbon potential and carbon sequestration process re-emphasizes the importance of maintaining, and where possible rehabilitating including introducing IMTA technology throughout the suitable locations of coastal region (Ahmed and. Glaser 2016), and such ecosystems will act as an opportunity for ecosystem climate change bio-mitigation and to also including them in carbon trading mechanisms.

\section{Oil, Gas and Minerals Mining}

\section{a. Oil and Gas Exploration}

Within the maritime territory of Bangladesh, there might be a number rich oil and gas reserves like India and Myanmar sites, which needs to be explored and exploited. Meanwhile, until 2014 Bangladesh drilled 20 wells in the offshore locations of the BoB but only two gas reserves were discovered (Hossain et al. 2014). So far, a total of 26 Trillion Cubic Feet (Tcf) gas reserve has been discovered in Bangladesh. Among those, the Sangu reserves having 0.8 Tcf discovered and already depleted. On the other hand, Kutubdia reserves having 0.04 Tcf are yet be developed. Drilling at two other offshore places viz. Magnama (3.5 Tcf) and Hatiya (1.0 Tcf) yet be developed and completed (Alam 2014).

In the country, Bangladesh Petroleum Exploration \& Production Company Limited (BAPEX) is the only authorized company to carry out oil and gas exploration and exploitation. In view of harnessing and identifying more potential oil and gas reserves a logical plan and framework need be established by the concerned ministry of the Govt. On the basis of that a thorough survey with the present boundary of BoB to be conducted and afterwards the qualified international companies should be appointed to accelerate offshore 
exploration and drilling activities to ensure the country's future energy security. Public and private partnerships are to be encouraged and allowed to share data and information, monitoring, and best practices, as well as monitoring and assessment protocols and results.

\section{b. Minerals mining}

Besides oil and gas, potential mineral resources yet to be explored within the maritime boundaries of $\mathrm{BoB}$ and heavy sedimentation might hinder significantly this possibility in particularly in the coastal areas. But there might be promising potentials of deposits of marine minerals from deep sea mining at the seabed areas to explore the elements belonging to the categories like i) polymetallic sulphides; ii) ferromanganese crusts; iii) ferromanganese nodules and iv) rate earth elements e.g. Yttrium etc. They differ in composition, shape and location. If these resources are managed correctly, this natural capital could be converted into jobs, infrastructure, public service improvements and growth in the domestic private sector (Alam 2014). According to Rona (2002) the new millennium has brought accelerating utilization of marine minerals, while knowledge of new types of marine mineral resources is expanding with significant present and potential scientific and economic benefits. No updated survey reports on heavy minerals availability at the sea bed and beach region in Bangladesh is available except the report of Bangladesh Atomic Energy Commission, BAEC (1994). According to this report the Beach Sand Exploration Center, Cox's Bazar compiled the information and data of earlier exploration conducted during 1968 to 1986, which were conducted throw-out entire south eastern and southern coastal areas along with its associated offshore islands (Table 7). The entire coastal belt has been explored with the discovery of 17 deposits of potentially valuable minerals such as zircon, rutile, ilmenite, leucoxene, kyanite, garnet, magnetite and monazite etc. (Alam 2004). For accelerating the mineral mining opportunities under blue economy it is extremely essential to update the potential evaluation first that was done in 1994. Then proceed to way forwards for further exploration even to the onshore, offshore and deep sea minerals mining.

Table 7. Heavy mineral reserves in the deposits along the coastal belt of Bangladesh (modified after Alam 2004)

\begin{tabular}{|l|l|l|l|l|l|l|l|}
\hline \multirow{2}{*}{$\begin{array}{l}\text { Reserve of } \\
\text { minerals } \\
\text { (in MT) }\end{array}$} & $\begin{array}{l}\text { Madar } \\
\text { mokam }\end{array}$ & Sabrang & Teknaf & Sikhali & Inani & $\begin{array}{l}\text { Cox's } \\
\text { Bazar }\end{array}$ & Kuakata \\
\hline Crude sand & $1,765,000$ & 347,556 & $1,939,580$ & $2,759,828$ & 729,286 & $5,119,000$ & $2,872,486$ \\
\hline $\begin{array}{l}\text { Heavy } \\
\text { minerals }\end{array}$ & 411,000 & 68,582 & 442,291 & 489,714 & 175,476 & 920,000 & 831,668 \\
\hline Zircon & 4,932 & 4,184 & 38,306 & 33,300 & 10,880 & 23,000 & 9,647 \\
\hline Rutile & 3,288 & 1,372 & 13,230 & 10,744 & 4,036 & 6,440 & 3,911 \\
\hline Ilmenite & 94,530 & 19,614 & 163,170 & 173,360 & 53,170 & 161,000 & 76,015 \\
\hline Leucoxene & 18,002 & 3,470 & 20,124 & 10,970 & 439 & 10,488 & 9,647 \\
\hline Kyanite & $-*$ & 727 & 14,728 & 4,407 & 1,404 & $-*$ & 16,800 \\
\hline Monazite & 4,932 & 206 & 3,045 & 3,918 & 965 & 2,024 & 83.2 \\
\hline Magnetite & 10,275 & 1,001 & 7,209 & 3,085 & 5,545 & 33,214 & 4,325 \\
\hline Garnet & $-*$ & 3,018 & 22,424 & 39,422 & 12,810 & 50,229 & 52,229 \\
\hline
\end{tabular}

*Not estimated 


\section{Marine Renewable Energy}

Naturally available energy sources viz. marine wind, wave, solar radiation, tide, water currents etc. could be utilized through the available or invented new technologies to convert as renewable energy as alternative for electric power supply generated from the fuel consumed power houses. In particularly for low cost electrification at homestead houses, small scale mills and industries at onshore areas and offshore islands of our coastal region. Apart with the oil and gas exploitation implementation programs, tremendous opportunities could also be harnessed in this sector. In this connection, necessary strategies and plans by respective ministries/departments need to be formulated and subsequently implement through some projects to identify feasible onshore locations at the coastal belt. And subsequently install the wind turbines or any other hydro-electric infrastructures to connect the generated power lines from the transmission grids with the suitable offshore areas. It has been reported that a wind generator with a capacity of $2 \mathrm{MW}$ already installed in the coastal area of Kutubdia island, Bangladesh, but it remains yet inactive (Hossain et. al. 2014 and Alam, 2014).

In this connection, suitable sites, technology transfer and training on renewable energy sources need to be explored to mitigate the increasing energy demand and a contribution to reduce global warming (Hossain et. al. 2014).

\section{Sea Salt Production}

Common salt, i.e. Sodium chloride $(\mathrm{NaCl})$ production through evaporating marine waters is a traditional ancient practice all over the world. The salt reserves in entire oceans have already been estimated over 50 million billion tonnes and these source cover over $50 \%$ of the world production (Mannar 1982). In Bangladesh, marine salt production has been traditionally produced mostly at Cox's Bazar coastal areas (Alam 2014). The onshore areas like Chakaria, Cox's Bazar, Banshkhali, Teknaf etc. and offshore islands like Moheshkhali, Kutubdia etc. are the potential areas of crude salt production at the salt pans during dry season (December - May). Average production of such crude salt is about $7000-10,000$ $\mathrm{kg} / \mathrm{ha}$. Alam (2014) reported those in places of the coast some farmers might be able to produce about $20,000 \mathrm{~kg} / \mathrm{ha} /$ season. Hossain et al. (2006) made a comparative report about the salt production areas and annual production rates of Cox's Bazar coast of Bangladesh (22 metric tonnes) and Samut Sakhon coast of Thailand (43 metric tonnes). They reported that most of the salt farms are small-scale, using manually operated local equipment and lease the land from landowners, or sometimes from the government on a yearly basis. Communityfocused land leasing systems, sufficient credit facilities, use of mechanical equipment (water pump, leveller, etc.) and reliable weather forecasting can enhance salt production. Moreover, formation of salt farmer's cooperatives can ensure bargaining power and maximize economic return (i.e., salt price) for their standard of living.

Recently, some of the advanced countries in Europe and North America are using modern techniques even collecting and refining common salt by mining. Such advanced 
technologies can also be introduced through public private partnership in near future under blue economy approach of the Govt.

\section{Marine Trade, Shipping and Transport}

The global trade is mostly handled and rotated by coastal ports and seaborne transportations. It is reported that about 80 percent of global trade by volume, and over 70 per cent by value, is carried by sea and handled by ports worldwide. For developing countries, on a national basis, these percentages are typically higher (Alam 2014). In particularly for Bangladesh, seaborne trade has been estimated over $90 \%$ and recent globalization pushed this trend towards further ahead. Alam (2014) pointed out that value of exported and imported goods of the country stands at about US\$ 67 billion (2013-14), which are transported by 2500 foreign ships visiting the country's sea ports. It is also estimated that against our import and export value, during last ten years, importers, exporters and buyers has paid US\$ 95 billion as freight and related charges to shipping companies, air lines and freight operators to carry goods in and out of Bangladesh.

There are scanty of modern merchant ships, so far a total of only 74 registered ships (2014) are available, which cannot support even a fraction of cargo goods (Alam 2014). In this context, the true potential is far from being tapped yet for Bangladesh's flag bearing cargo fleets. Local shipping companies needs to come forward to add more fleets including the expansion of fleet in terms of size and capacity to lift the economic face of the country in a short time (Hossain et al. 2014). Along with this concerned ministry and department should make effective planning and actions to enhance marine trade, shipping and transport related activities to secure jobs for the people and foreign exchange earnings.

\section{Marine Tourism}

Marine tourism could be one of the important sources of income in Bangladesh like other coastal countries of the world. It is estimated that in 150 countries, tourism is one of the five top export earners and in 60 countries it is the first earning source and it is the main source of foreign exchange for one half of the LCD countries (Alam 2014). There are plenty of opportunities to develop this sector at the onshore and offshore coastal areas of the country. Many well off private parties are interested to join and share their capital investment in coastal tourism, so concerned ministry(s) and department(s) should come forward to make national strategy for well-planned tourism as well as to facilitate and accelerate this sector. In this connection, lessons can be learned from neighbouring countries like Maldives, Malaysia, Myanmar and Thailand. Introduction of small and medium sized luxury cruise and catamaran ships and construction of modern hotels, cottages and restaurants need to be made at the tourist spots along the onshore and offshore coastal locations. Some of excellent spots for coastal tourism in Bangladesh listed in Table 8.

Table 8. Marine tourism spots at the onshore and offshore locations of coastal region in Bangladesh

\begin{tabular}{|l|l|l|}
\hline Division & Location & Tourism spots \\
\hline Chittagong & Southern & $\begin{array}{l}\text { Patenga beach; Cox's Bazar } \\
\text { Beach; Himsory and Inani }\end{array}$ \\
\hline
\end{tabular}




\begin{tabular}{|l|l|l|}
\hline & & $\begin{array}{l}\text { Beach; St. Martin's island and } \\
\text { beach; Moheshkhai island; }\end{array}$ \\
\hline Khulna & Southwest & Sundarbans mangrove forests \\
\hline Barisal & Southwest & $\begin{array}{l}\text { Kuakata beach; Bhola and } \\
\text { Monpura islands }\end{array}$ \\
\hline
\end{tabular}

By massive expanding of marine tourism sector, side by side with foreign exchange earnings, there will be a scope of additional business of rich and middle class people and jobs for hundreds and thousands of job seekers in different categories.

\section{Maritime Education and Research}

The multi-disciplinary sectors under the blue economy require highly skilled technical manpower and motivated cadre of research scientists. In particularly for maritime education, there are many academies and institutions in China, UK, France, Germany, Japan, Australia and USA. Although in Bangladesh, there a number of public and private universities and academies/departments, where marine and oceanography related subjects are taught under a limited technical facilities. The country presently needs to have a large group of appropriate human resources in the field of oceanography, marine dynamics, marine engineering, biotechnology, marine fisheries, marine trade, offshore engineering, naval architectural engineering, marine geological aspect, marine environment and ecosystem science etc. for sustainable blue economy growth and better utilization of maritime resources. In view of strengthening maritime education, Bangladesh Govt. has initiated to develop nation's human capacity with the creation of a Department of Oceanography at the Dhaka University and new Maritime University. In this context, there are scopes and opportunities for an equitable and mutually beneficial collaboration between Bangladesh's newly established Maritime University/and Oceanography department of DU and other European/international universities to develop high tech. multi-disciplinary education systems.

In regard to maritime research, no solely technical institutions were available in Bangladesh except the Marine and Technology Station of Bangladesh Fisheries Research Institute (BFRI). Research facilities at BFRI's marine research station in Cox's are not yet adequate to carry out need based marine and oceanographic research. To support this area, recently the National Oceanographic Research Institute (NORI) has been initiated for coastal and oceanic research at Ramu Cox's Bazar, which is presently under construction (Alam 2014).

\section{Maritime Surveillance}

Within the present maritime boundary, Bangladesh owns 47,211 sq. km of coastal area, which is approximately $32 \%$ of the total mass of the country (Banerjee, 2013). The marine and associated coastal zone is consisted of sprawling estuaries, dense mangrove forests, land and coral islands and sea beaches (Parvez, 2012). From the coast line onwards at the vicinity of territorial sea, EEZ and up to the entire zone of continental shelf, there are plenty of living and non-living resources like fisheries, oil and gas, valuable minerals etc. in the $\mathrm{BoB}$ area of Bangladesh. Aside with aquatic and fisheries resources, the possibility of exploring more gas and oil field is becoming more potential and challenging. The foot of the 
continental slope in the Bay of Bengal is at an average distance of 50 nautical miles and there is estimation that the area is potentially rich in oil and gas. Significant amount of natural gas is discovered in the off shore of Bangladesh while the same has been reported off the coast of Andhra Pradesh in India (Rahman, 2007).

Strengthening of maritime security and surveillance is becoming most important to protect these resources from international piracy and IUU fishing within the BoB part of Bangladesh. Similar situation also lies with the maritime resources of other neighbouring states i.e. India, Myanmar and Sri Lanka. Issues of piracy and illegal maritime activities can best be addressed through cooperative surveillance and information sharing arrangements (Alam, 1997). It is the high time for South Asian littoral states (Bangladesh, India and Sri Lanka) including Myanmar of the Bay of Bengal to outline a coordinated approach to security risk management from regional level to enhance regional maritime security and surveillance against international threat and terrorism (Rahman, 2013).

\section{Marine Spatial Planning}

The coastal country like Bangladesh immensely need to implement an integrated policy, legal framework and management issues because of winning a wide maritime area in the BoB after the settlement of boundary disputes with India and Myanmar. Marine Spatial Planning (MSP) formulation, properly design and running is presently very much important for Bangladesh to manage and use blue economy resources by a placed based integrated plan among various entities of a costal state for sustainable use as well as sustainable development (Alam 2016). It is a process that brings together multiple users of the ocean including trade, energy, industry, government, conservation and recreation to make informed and coordinated decisions about how to use marine resources sustainably. Bangladesh needs to run for an effective MSP to ensure a stabilized and sustainable blue economy through policy and legal protection despite of a number of challenges.

Although in a number of reports including FAO's resent $7^{\text {th }}$ Five Year Plan for Ocean and River management, where number of essential tools was outlined including MSP but it does not prescribe any policy or action of planning for adopting an integrated legislation to initiate MSP for Bangladesh (Hossain et al, 2014). So, the time is extremely crucial to formulate an effective policy and strategy for MSP at national level with the initiative of an authorised body under the auspices of PM's office for sector by sector planning of the blue economy of Bay of Bengal. The Plan should be integrated and multi-objective, strategic and future-oriented, and continuous and adaptive, which should frame work and be developed and run by a special task force at the highest level of the Govt. (Alam 2016). For achieving sustainable blue growth, Bangladesh must drive all maritime resources within the framework of well-designed MSP, if the country misses this opportunity it will a big loss to achieve sustainable goal of development, and utilization of available marine resources and protection of coastal and marine environment as a whole. 


\section{Discussions}

In Bangladesh due to lack of implementation and enforcement of management measures, many opportunities in marine resources development remain untapped. Presently, in particularly for marine fish stock capture and harvesting a limited number of commercial trawlers (247 trawlers), huge number of motor drive (32,859 boats) and non-motor drive (34,810 boats) artisanal boats are engaged in marine and coastal fishing (DoF, 2016). In particularly the artisanal fishermen are using different types of net having unregulated mesh size for harvesting marine small and big fish in the shallow coastal areas. After harvest they mostly separate medium and large size fish for selling to the local markets and rest of the harvested stocks consisting of millions of various varieties of tiny marine fish fry and juveniles never release into the sea waters and dump at the boat bottom chambers and baskets as trash fish. In the following morning, most of those boats back to the shore and sell all these as trash fish to local buyers as raw materials for fish and poultry feeds. No regulation and enforcement measures have yet been undertaken on these issues by the respective ministry/departments As a result, marine fish biodiversity is being declining day by day, which is dangerous for future sustainable management of marine stocks in Bangladesh. Another management issue remain an obstacle in the country, until today, marine fish stocks are being assessed and based on fragmented and less reliable catch data from commercial vessels. This situation obviously leads the sector towards overexploitation. It has been already observed in recent declining trends of the catch per unit effort (CPEU) in BoB fishing grounds and indiscriminate and uncontrolled use if fish detection technologies might be destructive to fish stocks (Hossain et al. 2014). Incapability in regard to harvesting and catching of large pelagic fish stocks in deep sea areas already exists in the country due to lack of modern crafts and gears. So the total marine catch remained limited around the shallower part of the continental shelf up to a maximum depth 200 meter. Most of the artisanal fishing boats and trawlers repeatedly harvesting shrimp and fish within $40-50$ meter water depth, as a result heavy fishing pressure did not allow sustainable recruitment of new stocks in those fishing grounds. Overall marine fish yield and production could not be flourished as per expectation. On the other hand due to inescapabilty in deep pelagic fish exploitation remained untapped since many decades.

In Bangladesh, no straight forward planning has yet been made to declare and establish specific Marine Protected Areas (MPA). The country should allocate at least $10 \%$ of its maritime area for such protection and conservation of marine habitat and ecosystem (Hossain et al. 2014). Planning and implementation of strategy for MPA is extremely essential for overall conservation of marine biodiversity at BoB area. So far reported IUCNBangladesh as a collaborating partner with regional BOBLME project was engaged to work on MPAs (Hoq et al. 2013). Marine Spatial Planning (MSP) in Bangladesh has not yet planned and designed in coordination of various stakeholders. The current practice of fragmented 'sector-by-sector' or 'use-by-use' planning, managed by discrete laws and regulations, and implemented by disconnected agencies and bodies, is causing competition or conflict among multiple users of the ocean (Hossain et al., 2014). It has been discussed earlier section that at the highest level of the government under the auspices of PM's office for an integrated coastal and ocean management policy and framework should be developed and run by a special task force. MSP should be integrated and multi-objective, strategic and future oriented, and continuous and adaptive to use all marine resources for sustainable blue growth 
(Hossain et al, 2014; Alam, 2016). Planning has not yet been made in the country to implement Ecosystem Approach to Fisheries Management (EAFM) according to FAO Code of Conduct, 1995 laid out as broad principles and approaches for effective and responsible fisheries management, which embody the concept of EAF (FAO 2003). EAF concept is essential for sustainable development and management of coastal and marine fisheries in Bangladesh (Hossain et al. 2014). There is lacking of planning to initiate application of marine biotechnology, estimation of carbon sequestration and extraction of marine minerals for successful development of blue economy. In regard to tourism, the concerned ministry and department of Bangladesh have no strategy for well-planned marine tourism; there is lack of planning for zoning of coastal and maritime areas and resources including ecosystem services. Although, this sector is passing crucial time for improvement in many aspects, related to modern facilities for incoming tourists at the available sea beaches and coastal tourist spots from different parts of the world. Similar situations also exist in lacking of planning in marine trade, shipping and transports; Oil, gas and mineral exploitation; marine minerals mining and other economic sectors. In regard to common salt production in the onshore areas like Chakaria, Cox's Bazar, Bashkhali, Technaf etc. and offshore islands like Moheshkhali, Kutubdia etc. at the salt pans during dry season (December - May), there is a serious gap of proper planning by the Govt. department and agencies. One recent survey in Kutubdia area revealed that two third of the rice cultivation lands have been converted to salt production since last 15 years due to intrusion of saline water every year through the collapsed surrounding embankment. No doubt salt production has increased per capita income rather than rice production for most of the local produces but in future, if salt production practices become less profitable due to fall of international demand and marketing, there will no chance of going back to rice or any other agriculture production due to extremely high salinity of the soil. In fact, the unplanned salt production is rather disaster for environment in Kutubdia and other areas in Cox's bazar.

One of the most important gaps for development of marine based economic sectors is the lack of coordination between and among the partners. In that case public private partnership is seriously hampering the development in particularly in the sectors like trade, shipping, tourism, oil and gas field exploration, fish preservation and marketing, ecosystem services, social welfare related to coastal dwellers etc. On the other hand, there is clear cut lacking of coordination between public administrations and research institutions; between administrations and private entrepreneurs/businessmen; between/among public and private sector agencies. Inter-ministerial coordination is very much vital to bring forward all the relevant developmental issues related to blue economy. Maritime Affairs Unit of Ministry of Foreign Affairs, Govt. of Bangladesh would play a vital role for bridging such coordination as soon as possible. Bangladesh is lagging behind than India and Myanmar obviously than other BoB countries for taking social and economic advantages from BE concept.

\section{Conclusions}

The Bay of Bengal and the coastal regions provide the backbone of the economy in Bangladesh. As highlighted in this paper (see Table 1), there are several sectors of the blue economy that offer potential for development to achieve food security and economic development objectives. The blue economy related economic activities can generate jobs and 
bring about significant tangible benefits to change the lives and livelihoods of millions of people living in the coastal areas. However, this can only be achieved with a government strategy in line with UNEP blue economy objectives, also with support from the international arena to protect the national interests and objectives of blue economy development in Bangladesh.

Integrated and inter-sectoral/inter-ministerial coordination including academiaindustry, public-private, resource-responsibility, and time-space are essential to bring forward the relevant issues related to blue economy development in Bangladesh. Marine Spatial Planning (MSP) can designate ocean spaces for specific uses such as marine cage farming, fishing zones for artisanal and industrial fishers, navigation routes for international and domestic shipping, marine protected areas (MPAs), marine fishing grounds, breeding grounds of valuable and important species, and migration routes of marine species to generate strong foundation for economic earnings and social benefits. Lessons can be learnt from developed nations such as the EU in pursuit of MSP to ensure that developments in the blue economy lead to sustainable outcomes in line with the country's development objectives.

\section{References}

Ahmed, N. and M. Glaser. 2016. Can "Integrated Multi-Trophic Aquaculture" adapt to climate change in Coastal Bangladesh. Ocean and Coastal Management 132:120-131

Alam, M, K. 2004. Bangladesh's maritime challenges in the 21st century. Dhaka: Pathak Shamabesh Book.

Alam, M. K. 1997. Regional maritime cooperation under the auspices of SAARC. BIISS Journal 1941.

Alam, M.K. 2014. Ocean/Blue economy for Bangladesh. In: Proceedings of International Workshop on Blue Economy, pp 28 - 49. Ministry of Foreign Affairs, Dhaka, Bangladesh.

Alam, M.A. 2016. Marine spatial planning: Bangladesh perspective. Asia Pacific Journal of Energy and Environment 3: 21-28. http://journals.abc.us.org/index.php/apjee/article/view/870

Anon. 2016. Blue economy interventions for food security in Bangladesh. Background Paper of National Seminar. Chittagong, Bangladesh. 6pp.

BAEC. 1994. Report of Beach Sand Exploitation Center, Cox’s Bazar. 23pp.

Banerjee, S. 2013. Vanishing Islands of Bangladesh. Retrieved from Down to Earth: http://www.downtoearth.org.in/content/vanishing-islands-bangladesh.

Belton B., M. Karim, S. Thilsted, K. Murshed-E-Jahan, W. Collis and M. Phillips. 2011. Review of aquaculture and fish consumption in Bangladesh. Studies and Reviews 2011-53. The WorldFish Center. November 2011. 72pp.

Bhuiyan, M.N.U., M.A. Ali, M.M. Rahman and S.A.M. Selim. 2015. Marine boundary confirmation of Bangladesh: Potentials of sea resources and challenges ahead. The Cost and Management 43: 7pp.

Cebrian, J. 2002. Variability and control of carbon consumption, export, and accumulation in marine communities. Limnology and Oceanography 47: 11-22. 
Chopin, T. 2011. Progress of the Integrated Multi-Trophic Aquaculture (IMTA) concept and up scaling of IMTA system towards commercialization. Aquaculture Europe 36:5-12.

Chmura, G.L., S.C. Anisfeld, D.R. Cahoon, and J.C. Lynch. 2003. Global carbon sequestration in tida 1, saline wetland soils. Global Biogeochemical Cycles 17. 1111.

Chowdhury, S.R. (2017). Maritime Province of Bangladesh, 2nd Ed (map). University of Chittagong, Bangladesh

Chowdhury, S. R., M. S. Hossain, S. M. Sharifuzzaman and S. Sarker. 2015. Blue Carbon in the Coastal Ecosystems of Bangladesh. Project Document, Support to Bangladesh on Climate Change Negotiation and Knowledge Management on Various Streams of UNFCCC Process Project, funded by DFID and Danida, implemented by IUCN Bangladesh Country Office.

DoF, 2016. National Fish Week 2016 Compendium. Department of Fisheries, Ministry of Fisheries and Livestock in Bangladesh. 148pp.

Duarte C.M., N. Marba, E. Gacia, J.W. Fourqurean, J. Beggins, C. Barron and E.T. Apostolaki. 2010. Seagrass community metabolism: Assessing the carbon sink capacity of seagrass meadows, Global Biogeochem Cycles 24.

FAO 2003. Fisheries Management: The Ecosystem approach of Fisheries, Food and Agriculture Organization of the UN, FAO Technical Guideline for Responsible Fisheries 4. Rome. 112pp.

Kibria, A.S.M. 2016. Studies on Integrated Multi-Trophic Aquaculture (IMTA) systems in freshwater ponds. PhD Thesis. Department of Aquaculture, Bangladesh Agricultural University, Mymensingh.

Hossain M.S., M.Z. Hossain and S.R. Chowdhury. 2006. An Analysis of Economic and Environmental Issues Associated with Sea Salt Production in Bangladesh and Thailand Coast. International Journal of Ecology and Environmental Sciences 32:159-172.

Hossain, M.S., S.R. Chowdhury, U.K. Navera, M.A.R. Hossain, B. Imam and S.M. Sharifuzzaman. 2014. Opportunities and strategies for ocean and river resources management. Background paper for preparation of the 7th Five Year Plan. FAO, Dhaka, Bangladesh. 61pp.

Hussain, M.G. and M.J. Rahman. 2010. Marine fisheries resources of Bangladesh: Stock status and management issues. pp 37-51. In Sustainable Management of Fisheries Resources of the Bay of Bengal (eds. M.G. Hussain and M.E. Hoq.). Support to BOBLME Project, Bangladesh Fisheries Research Institute, Bangladesh.

Hoq, M.E., A.K.Y.Haroon and S.C. Chakraborty. 2013. Technical outcomes of the BOBLME project in Bangladesh. Support to Sustainable Management of the BOBLME Project. Bangladesh Fisheries Research Institute, Bangladesh. SBOBLME Pub./Rep. 09. 32pp.

Mannar, M.G.V. 1982. Guidelines for the establishment of solar salt facilities from seawater. underground brines and salted lakes. Industrial and Technological Information Bank (INTIB), Industrial Information Section, United Nations Industrial Development Organization (UNIDO), UNIDO Technology Program. 149pp.

MoFA 2014a. Press Release: Press statement of the Hon'ble Foreign Minister on the verdict of the Arbitral Tribunal/PCA. Dhaka, 08 July 2014. (Ministry of Foreign Affairs) url: http://www.mofa.gov.bd/PressRelease/PRDetails.php?txtUserId=\&PRid=854

MOFA 2014b. Proceedings of International Workshop on Blue Economy, Dhaka, Bangladesh 1-2 September, 2014. 88pp. 
Nellemann. C., E. Corcoran, C.M. Duarte, L. Valdés, C. De Young, L. Fonseca and G. Grimsditch. 2009. Blue Carbon. A Rapid Response Assessment. United Nations Environment Programme, GRIDArendal, www.grida.no

Parvez, M. S. 2012. Bay of Bengal prospects towards national flourishment. Retrieved from BD Fish: http://en.bdfish.org/2012/03/bay-of-bengalprospects-towards-national-flourishment/

Rahman, M. H. 2007. Legal regime of marine environment in the Bay of Bengal. New Delhi: Atlantic Publishers and Distributors.

Rahman, M. R. 2013. Regional cooperation in maritime security: A view from the Bay of Bengal. Annual International Studies Convention 2013, organized by Jawaharlal Nehru University (JNU), New Delhi, India, 10-12 December, 2013. https://ssrn.com/abstract=2369076

Rona P.A. 2002. Marine minerals for the 21st century, Episodes, 25:2-12.

Thakur, N.L. and A.N. Thakur. 2006. Marine biotechnology: An overview. Indian Journal of Biotechnology 5:263-268.

Trumper, K., M. Bertzky, B. Dickson, G. van der Heijden, M. Jenkins and P. Manning. 2009. The Natural Fix? The role of ecosystems in climate mitigation. A UNEP rapid response assessment. UNEP, UNEPWCMC, Cambridge, UK, 65pp. http://www. unep.org/pdf/ BioseqRRA_scr.pdf.

Valiela, I., J.L. Bowen and J..K York. 2001. Mangrove forests: One of the worlds threatened major tropical environments. BioScience 51:807-815.

Zilinskas, R.A., R.R. Colwell, D.W. Lipton and R.T. Hill. 1995. The Global Challenge of Marine Biotechnology: A Status Report on the United States, Japan, Australia and Norway. University of Maryland Sea Grant. UM-SG-TS-95-01. 372pp. 